REFLEKSI EDUKATIKA : Jurnal Ilmiah Kependidikan

Volume 11 Nomor 1 Desember 2020

ISSN: 2087-9385 (print) dan 2528-696X (online) http://jurnal.umk.ac.id/index.php/RE

\title{
PENDIDIKAN KARAKTER BERBASIS GERAKAN LITERASI DI SEKOLAH DASAR
}

\author{
Sri Subiyanti ${ }^{1}$, Murtono $^{2}$, dan Su'ad $^{3}$ \\ ${ }^{1,2,3}$ Universitas Muria Kudus, Indonesia \\ Email: Biyanti.be12sri@gmail.com
}

\section{Info Artikel}

Sejarah Artikel:

Diserahkan 28 Februari 2020

Direvisi 15 Juli 2020

Diterima 15 Oktober 2020

\section{Keywords:}

character education, school literacy movement, module

\begin{abstract}
The purpose of this study was to develop and test the effectiveness of the character education module based on the school literacy movement.

This type of research uses Research and Development (RnD). The research subjects used were fifth grade elementary school students in the RA Kartini Cluster, Jaken District, Pati Regency. Data collection techniques by means of observation, interviews, documentation, and questionnaires. The data was collected using observation sheets, interview sheets, photos of activities, and filling out questionnaires. Sources of data obtained from filling out questionnaires, observations, and responses from school principals, class teachers, subject teachers, students, and school committees on the implementation of the module. The resulting module is validated by material experts and module experts. Small group trials were conducted in fifth grade SDN Mojoluhur, Jaken District, Pati Regency. Meanwhile, product use trials were carried out in fifth grade SDNs in the RA Kartini Cluster, Jaken District, Pati Regency. Data analysis techniques are data collection, data presentation, and drawing conclusions and using the t-test to determine the effectiveness of the module. The questionnaire instrument test used validity and reliability, while the quality of the module in the study used expert validation.

The results showed: (1) a character education module developed based on the school literacy movement for elementary schools; (2) the character education module based on the school literacy movement is declared valid, the percentage of eligibility criteria for the validator is $75 \%$ (feasible) and $83 \%$ (very feasible); (3) the character education module based on the school literacy movement is effective for instilling character education in elementary school students. This is shown in the t test the effectiveness of $-121.696<1.86$ was obtained and the average student character questionnaire before and after using the module increased by 30.08\%; (4) the results of teacher responses from observations showed $75.6 \%$ (good).
\end{abstract}

\begin{abstract}
Abstrak
Tujuan penelitian ini adalah mengembangkan dan menguji keefektifan modul pendidikan karakter berbasis gerakan literasi sekolah.

Jenis penelitian ini menggunakan Research and Development (RnD). Subyek penelitian yakni siswa kelas V sekolah dasar di Gugus RA Kartini Kecamatan Jaken Kabupaten Pati. Teknik pengumpulan data dengan cara observasi, wawancara, dokumentasi, dan angket. Pengumpulan data dilakukan dengan menggunakan lembar observasi, lembar wawancara, foto kegiatan, dan pengisian angket. Sumber data diperoleh dari pengisian angket, observasi, dan tanggapan dari kepala sekolah, guru kelas, guru mapel, siswa, dan komite sekolah terhadap pelaksanaan modul. Modul yang dihasilkan divalidasi oleh ahli materi dan ahli modul. Uji coba kelompok kecil dilakukan di kelas V SDN Mojoluhur Kecamatan Jaken Kabupaten Pati. Sedangkan uji coba pemakaian produk dilakukan di SDN kelas V se-Gugus RA Kartini Kecamatan Jaken Kabupaten Pati. Teknik analisis data adalah pengumpulan data, penyajian data, dan penarikan kesimpulan serta menggunakan uji-t untuk mengetahui efektivitas modul. Uji instrumen angket menggunakan validitas dan reliabilitas, sedangkan kualitas modul dalam penelitian menggunakan validasi ahli.

Hasil penelitian menunjukkan: (1) modul pendidikan karakter yang dikembangkan berbasis gerakan literasi sekolah untuk sekolah dasar; (2) modul pendidikan karakter berbasis gerakan literasi sekolah dinyatakan valid, didapatkan presentase kriteria kelayakan validator $75 \%$ (layak) dan $83 \%$ (sangat layak); (3) modul pendidikan karakter berbasis gerakan literasi sekolah efektif untuk menanamkan pendidikan karakter pada siswa SD hal ini ditunjukkan pada uji t diperoleh efektifitas $-121,696<1,86$ dan rata-rata angket karakter siswa sebelum dan sesudah menggunakan modul naik 30,08\%; (4) hasil respon guru dari hasil observasi menunjukkan 75,6\% (baik).
\end{abstract}




\section{PENDAHULUAN}

Pendidikan merupakan alat kebangkitan bangsa dan senjata untuk mewujudkan kemajuan dan kemakmuran. Indikasi yang paling dominan untuk menunjukkan suatu peradaban maju dari sebuah bangsa yaitu ketika sektor pendidikannya berkualitas baik. Pendidikan yang berkualitas baik adalah pendidikan yang didalamnya mampu mendidik generasi bangsa menjadi generasi cerdas dan memiliki karakter yang baik.

Pendidikan karakter merupakan suatu proses yang digunakan untuk membentuk individu yang berkarakter atau berkepribadian. Gaffar dalam Kesuma (2011) menyatakan bahwa pendidikan karakter merupakan sebuah proses transformasi nilai-nilai kehidupan untuk ditumbuhkembangkan dalam kepribadian seseorang, sehingga menjadi suatu kebiasaan dalam perilaku kehidupan orang tersebut.

Pendidikan karakter kini marak dilakukan di sekolah-sekolah baik melalui literasi hingga diimplementasikan ke dalam pembelajaran. Dengan mengukur kualitas pendidikan maka dapat melihat potret bangsa yang sebenarnya, karena aspek pendidikanlah yang menentukan masa depan seseorang dengan melalui literasi yang diterapkan di sekolah.

Dalam kurikulum 2013, sudah disosialisasikan tentang penerapan pendidikan karakter di sekolah dasar. Tetapi hal ini belum mampu meningkatkan karakter baik siswa sekolah dasar. Masih banyak siswa yang melanggar tata tertib sekolah, masih ada kasus bullying, bertengkar, mencontek, dan mencuri uang teman di sekolah. Padahal usia anak sekolah dasar adalah usia memperoleh pendidikan karakter yang baik sebagai jembatan untuk menuju masa remaja (Khoury, 2017).

Apabila hal tersebut tidak segera diatasi maka akan menyebabkan menurunnya moral generasi penerus bangsa. Akhirnya tujuan kurikulum 2013 yang awalnya untuk mencetak generasi emas tahun 2045 tidak akan terwujud dengan maksimal. Sehingga penguatan pendidikan karakter menjadi penting dalam rangkaian proses pendidikan di sekolah karena investasi masa depan dalam ranah peradaban dipertaruhkan (Siregar, 2018).

Dalam rangka penguatan pendidikan karakter di sekolah-sekolah maka banyak peneliti telah melakukan riset, antara lain oleh Fakhriyah, Roysa, dan Sumaji (2014); Rachman, et al. (2017). Riset Fakhriyah, Roysa, dan Sumaji
(2014) menemukan adanya pengaruh positif sebagai dampak mengimplementasikan pembelajaran tematik berwawasan multiple intellegence terhadap hasil belajar dan karakter siswa. Karakter yang ikut terbentuk dalam pembelajaran ini meliputi karakter demokratis, rasa ingin tahu, mandiri dan tanggung jawab. Penelitian Rachman, et al. (2017) menyimpulkan bahwa model akhir manajemen pelatihan dan pengembangan pendidikan karakter berlokus padepokan karakter ini memiliki kebaruan berupa akomodasi berbagai anasir dalam pendekatan pendidikan karakter, yang disusun secara sistematis sejak perencanaan, pelaksanaan sampai evaluasi kegiatan pelatihan.

Pada abad ke-21 ini, kemampuan berliterasi sangat diperlukan oleh pemangku kepentingan di dunia pendidikan, utamanya peserta didik. Kemampuan berliterasi peserta didik berkaitan erat dengan tuntutan pendidikan karakter yang berujung pada kemampuan memahami informasi hingga karakter baik pada anak muncul melalui keteladanan dalam berliterasi. Akan tetapi, fakta pembelajaran di sekolah saat ini belum mampu mewujudkannya dengan baik. Tuntutan keterampilan abad 21 yang harus dikuasai dan pembelajaran di sekolah yang belum mampu menumbuhkan pendidikan karakter sehingga menjadi dasar utama literasi harus dikembangkan.

Kemampuan literasi peserta didik dan pendidikan dalam pembelajaran telah menarik perhatian para peneliti untuk melakukan riset, antara lain oleh Masfuah (2015); Ismaya (2017) dan Suntoro (2019). Riset Masfuah (2017) menemukan bahwa berdasarkan analisis data yang telah dilakukan dengan uji regresi, didapatkan persamaan $\hat{Y}=1,006 X-10,17$ dan didapatkan hasil koefisien korelasi antara kecakapan personal dengan literasi sains siswa (rXY) sebesar 0,56 yang berarti terdapat hubungan positif antara kecakapan personal dengan kemampuan literasi sains siswa. Selanjutnya, diperoleh nilai koefisien determinasi (r) sebesar 0,314 yang berarti bahwa $31 \%$ kemampuan literasi sains dipengaruhi oleh kecakapan personal, sedangkan $69 \%$ dipengaruhi oleh faktor lain.

Penelitian Ismaya (2017) menunjukkan bahwa pembelajaran konsep ilmu pengetahuan sosial berbasis literasi informasi yang dilaksanakan, bisa diterima dengan baik oleh mahasiswa. Mahasiswa mampu menemukan 
informasi dan membangun pengetahuan serta pemahaman terhadap konsep-konsep ilmu pengetahuan sosial dengan benar. Konten lokal yang disajikan sebagai bahan pengayaan dalam pembelajaran konsep ilmu pengetahuan sosial turut memperkuat pengetahuan dan pemahaman mahasiswa serta dapat mendukung pencapaian visi Universitas Kebudayaan. Lebih lanjut, riset Suntoro (2019) menemukan bahwa (1) kebutuhan informasi guru PAB di Kabupaten Pati secara umum dapat diklasifikasikan menjadi kebutuhan informasi untuk peningkatan kompetensi guru dan kebutuhan informasi untuk peningkatan karier; (2) akses informasi bersumber dari berbagai lokasi, para guru juga telah mampu menganalisis, mengorganisasi, danmenyimpan perolehan informasi dengan baik; (3) guru memanfaatkan hasil literasi informasi dalam kegiatan belajar mengajar di sekolah meskipun mengalami kendala seperti minimnya sarana prasarana penunjang pembelajaran.

Gambaran situasi dunia pendidikan di Indonesia menjadi motivasi pokok implementasi pendidikan karakter di Indonesia. Bahkan berdasarkan hasil observasi di Gugus RA Kartini Kecamatan Jaken Kabupaten Pati pendidikan karakternya dirasakan amat perlu pengembangannya bila mengingat makin meningkatnya pertengkaran antar siswa di sekolah, pemerasan/kekerasan (bullying), kecenderungan dominasi senior terhadap yunior, merokok, dan suka mencuri barang/uang milik temannya.

Di Gugus RA Kartini Kecamatan Jaken Kabupaten Pati ini telah dilakukan pembenahan rendahnya karakter siswa di sekolah dasar dengan menerapkan pendidikan karakter terintegrasi dalam pembelajaran sesuai tuntutan kurikulum 2013. Namun demikian, hal ini belum dapat memberikan solusi yang optimal untuk mengatasi rendahnya karakter siswa karena sampai saat ini masih banyak terlihat sikap yang menunjukkan rendahnya karakter siswa.

Pala (2011) menyatakan bahwa pendidikan karakter harus dilaksanakan dengan menggunakan pedoman untuk membantu siswa mengembangkan karakter yang baik, meliputi pengetahuan, peduli, dan bertindak berdasarkan nilai-nilai etika. Oleh karena itu, untuk mengantisispasi rendahnya pendidikan karakter pada siswa di Gugus RA Kartini kecamatan Jaken Kabupaten Pati, maka peneliti mengembangkan modul pendidikan karakter berbasis gerakan literasi sekolah sebagai program penumbuhan budi pekerti siswa sekolah dasar.

Modul pendidikan karakter berbasis gerakan literasi sekolah merupakan sebuah petunjuk pelaksanaan program pendidikan karakter berbasis gerakan literasi sekolah pada satuan pendidikan dalam menerapkan pendidikan karakter melalui gerakan literasi sekolah. Modul yang dikembangkan berisi program pelaksanaan pendidikan karakter melalui gerakan literasi sekolah, dimana yang digunakan dalam penelitian ini ada lima sekolah dasar. Masingmasing sekolah dasar mengembangkan dan fokus pada satu karakter saja. Kemudian setiap hari Sabtu diadakan belanja karakter ke sekolah lain yang mengembangkan karakter yang berbedabeda secara bergantian. Sehingga di akhir kegiatan belanja karakter, masing-masing sekolah dapat menguasai lima karakter untuk dikembangkan di sekolahnya sendiri. Dalam modul juga diuraikan kegiatan pendampingan serta kegiatan evaluasi terhadap implementasi modul pendidikan karakter berbasis gerakan literasi sekolah.

Pengkajian implementasi pendidikan karakter berbasis gerakan literasi sekolah di sekolah dasar ini diharapkan dapat membentuk karakter siswa sejak usia dini melalui kegiatan literasi di sekolah dasar. Hal ini didukung oleh pendapat Hendarrman, et al. (2017) dan Wiratsiwi (2020). Hendarrman, et al. (2017) menyebut bahwa gerakan literasi merupakan kegiatan mengasah kemampuan mengakses, memahami, mengolah, dan memanfaatkan informasi secara kritis dan cerdas berlandaskan kegiatan membaca, menulis, menyimak, dan berbicara untuk menumbuhkembangkan karakter seseorang menjadi tangguh, kuat, dan baik. Sementara itu Wiratsiwi (2020) menemukan bahwa Dalam penerapan Gerakan Literasi Sekolah di Gugus 01 Kecamatan Singgahan masih terdapat beberapa kendala diantaranya yaitu : 1) masih kurangnya buku bacaan; 2) kurangnya minat membaca siswa; 3) guru belumsepenuhnyamenjalankankegiatanini; 4) kurangnya pembinaan dari pihak dinas pendidikan setempat tentang Gerakan Literasi Sekolah ini; 5) serta orang tua siswa yang agak acuh terhadap kebutuhan anak dalam rangka menunjang Gerakan Literasi Sekolah.

Berdasarkan latar belakang diatas, penelitian ini bertujuan untuk (1) menghasilkan 


\section{Sri Subiyanti, Murtono, Su'ad \\ PENDIDIKAN KARAKTER BERBASIS GERAKAN LITERASI DI SEKOLAH DASAR \\ REFLEKSI EDUKATIKA : Jurnal Ilmiah Kependidikan, Volume 11, Nomor 1, Desember 2020, hlm. 24-34}

produk modul pendidikan karakter berbasis gerakan literasi sekolah; (2) mengetahui tingkat kelayakan modul pendidikan karakter berbasis gerakan literasi sekolah; (3) mengetahui efektifitas penerapan kelayakan modul pendidikan karakter berbasis gerakan literasi sekolah; (4) mengetahui dampak pelaksanaan modul pendidikan karakter berbasis gerakan literasi sekolah melalui respon guru SD.

\section{METODE PENELITIAN}

Metode penelitian yang digunakan pada penelitian ini yaitu penelitian pengembangan (Research and Development). Langkah-langkah penelitian pengembangan menurut Sugiyono (2014) yaitu (1) potensi dan masalah, (2) pengumpulan data, (3) desain produk, (4) validasi desain, (5) revisi desain, (6) uji coba produk, (7) revisi produk, (8) uji coba pemakaian, (9) revisi produk, dan (10) produksi massal.

Ruang lingkup atau objek dalam penelitian ini adalah pengembangan modul pendidikan karakter berbasis gerakan literasi sekolah. Karakter yang dikembangkan dalam penelitian ini yakni disiplin, gemar membaca, tanggung jawab, rasa ingin tahu, dan komunikatif/bersahabat. Sedangkan gerakan literasi sekolah dijabarkan menjadi beragam kegiatan melalui tahap pembiasaan, pengembangan, dan pembelajaran. Dengan kegiatan literasi sekolah yang dikembangkan dalam sebuah modul, maka akan dapat terbentuk karakter yang baik bagi siswa. Hal itu akan menumbuhkembangkan budi pekerti anak sejak dini melalui pembudayaan kegiatan literasi sekolah agar menjadi insan yang berkarakter dan berdedikasi tinggi.

Subyek penelitian yakni siswa kelas lima sekolah dasar di Gugus RA Kartini (SDN Sukorukun, SDN Tegalarum, SDN Sumberejo, SDN Mojoluhur, dan SDN Kebonturi) Kecamatan Jaken Kabupaten Pati. Waktu penelitian dilakukan pada semester ganjil 2019/2020. Jangka waktu penelitian selama tiga bulan dari Agustus sampai dengan Oktober 2019.

Teknik pengumpulan data meliputi data kualitatif dan kuantitatif hasil observasi, wawancara, angket, dan dokumentasi. Instrumen yang digunakan berupa lembar wawancara dari kepala sekolah, lembar observasi dari guru, pengisian angket oleh kepala sekolah, guru, siswa, komite sekolah, dan portofolio siswa hasil implementasi modul pendidikan karakter berbasis gerakan literasi sekolah. Sebelum digunakan dalam penelitian, angket diuji validitas dan reliabilitasnya.

Data yang sudah dikumpulkan kemudian diolah dan dianalisis. Pengolahan dan analisis data kualitatif dilakukan melalui tahapan pengumpulan data, menyajikan data, dan menarik kesimpulan. Data berupa wawancara dan observasi dianalisis secara kualitatif. Sedangkan analisis data akhir kuantitatif berupa angket merupakan suatu analisis yang digunakan untuk menganalisis kefektifan modul pendidikan karakter berbasis gerakan literasi sekolah, yaitu dengan menggunakan analisis uji t. Kemudian hasil observasi dianalisis untuk mendeskripsikan dampak penggunaan modul pendidikan karakter berbasis gerakan literasi sekolah.

\section{HASIL DAN PEMBAHASAN}

\section{A. Hasil Penelitian}

\section{Potensi dan Masalah}

Pada tahapan ini, peneliti melaksanakan pra penelitian untuk mendapatkan potensi dan masalah yang ada di sekolah. Pra penelitian dilaksanakan pada awal semester ganjil di sekolah dasar Gugus RA Kartini Kecamatan Jaken Kabupaten Pati. Pengumpulan data pra penelitian dilakukan dengan cara observasi dan wawancara, mengumpulkan informasi tentang penerapan pendidikan karakter di SD kelas tinggi khususnya di SD se-Gugus RA Kartini.

Berdasarkan pra penelitian yang dilakukan, didapatkan potensi dan masalah yang terkait dengan penerapan pendidikan karakter. Pendidikan karakter masih diterapkan secara terintegrasi dengan pembelajaran yang dibuktikan pada rancangan pelaksanaan pembelajaran yang digunakan oleh guru. Sehingga pelaksanaan pendidikan karakter belum terimplementasi dengan baik akibatnya masih banyak siswa yang melanggar tata tertib sekolah dan tidak sesuai dengan aturan yang berlaku dengan baik. Adanya gedung perpustakaan dan beragam bahan literasi hanya dimanfaatkan sebagai kegiatan membaca 15 menit sebelum pelajaran saja. Pemanfaatan literasi kurang maksimal, padahal sarana dan prasarana dapat dimanfaatkan dengan maksimal,

Adanya potensi dan masalah, maka perlu dilakukan proses pembenahan implementasi pendidikan karakter dan pembiasaan minat baca. 


\section{Desain Produk}

Peneliti telah mengembangkan produk modul pendidikan karakter berbasis gerakan literasi sekolah. Modul pendidikan karakter berbasis gerakan literasi sekolah artinya dalam kegiatan pelaksanaan proses penanaman pendidikan karakter di sekolah dasar, guru dapat mengintegrasikan kegiatan yang dilakukan melalui gerakan literasi sekolah. Guru dapat menerapkan pendidikan karakter berbasis gerakan literasi sekolah ini secara bertahap dan menyesuaikan dengan kondisi satuan pendidikan serta latar belakang siswa. Program gerakan literasi sekolah yang digunakan dalam menanamkan pendidikan karakter dapat diiplementasikan secara berkesinambungan untuk membiasakan siswa gemar membaca dan menciptakan lingkungan yang berkarakter.

\section{Hasil Uji Coba Produk}

a. Validasi Desain Modul Pendidikan Karakter Berbasis Gerakan Literasi Sekolah

Uji kelayakan pada tahap validasi desain terdiri dari aspek kelayakan isi modul, kelayakan pelaksanaan, aspek kelayakan bahasa, dan kelayakan kegiatan siswa. Modul divalidasi oleh validator ahli materi dan ahli modul. Perolehan skor dari validator ahli materi adalah $83 \%$ (sangat layak) dan validator ahli modul adalah $75 \%$ (layak).

b. Revisi Desain

Revisi desain diperoleh dari saran dan komentar baik yang dilakukan validator dalam lembar validasi maupun secara lisan. Ada beberapa saran yang didapatkan setelah validasi desain dilakukan. Beberapa saran tersebut yaitu: komposisi materi yang perlu dirinci menjadi per bab, materi yang harus sesuai dengan redaksi pendukung, tata kelola layout gambar dan komposisi tampilan dari mulai sampul depan sampai sampul akhir. Semua bagian isi dari program pelaksanaan kegiatan pendidikan karakter berbasis gerakan literasi sekolah disertai dengan contoh kegiatan faktanya di sekolah.

c. Uji Coba Produk Kelompok Kecil

Pelaksanaan uji coba kelompok kecil dilakukan di SDN Mojoluhur Kelas V dengan jumlah 15 siswa. Uji coba kelompok kecil dilakukan dengan memberikan program pendidikan karakter berbasis gerakan literasi sekolah dengan satu sekolah dasar langsung mengembangkan lima karakter yaitu disiplin, gemar membaca, tanggung jawab, rasa ingin tahu, dan komunikatif/bersahabat. Sebelum dan sesudah mendapatkan perlakuan program pendidikan karakter berbasis gerakan literasi sekolah ini, siswa diminta untuk memberi tanggapan mereka melalui mengisi angket tentang keterlaksanaan program pendidikan karakter ini.

Tujuan pelaksanaan uji coba kelompok kecil ini adalah untuk menguji modul pendidikan karakter berbasis gerakan literasi sekolah untuk melihat respon dan komentar sebelum diujicobakan pada skala yang lebih besar. Ratarata hasil tanggapan siswa berdasarkan angket yang telah diisi, antara sebelum dan sesudah pelaksanaan program pendidikan karakter, yang awalnya rata-rata $14,88 \%$ naik menjadi $15,62 \%$. Artinya program ini dapat memperbaiki karakter siswa dan mendapat respon baik dari siswa, tetapi perlu direvisi lagi dalam pengimplementasiannya supaya siswa lebih tertarik dalam kegiatan ini.

Akhirnya, program pendidikan karakter berbasis gerakan literasi ini dilaksanakan dengan melibatkan lima sekolah dasar di Gugus RA Kartini. Masing-masing sekolah mengembangkan satu karakter saja. Kemudian setiap hari Sabtu, keempat SD yang lain mengunjungi satu SD untuk berbelanja karakter/study banding. Begitu seterusnya bergantian berkunjung ke SD yang lain karakternya. Sehingga masing-masing SD dapat menguasai lima karakter yang dikembangkan di Gugus RA Kartini dan menerapkan karakter tersebut di satuan pendidikannya secara berkesinambungan dan konsisten.

d. Uji Coba Pemakaian

Uji coba pemakaian dilaksanakan di siswa kelas V (SDN Sukorukun, SDN Tegalarum, SDN Sumberejo, SDN Mojoluhur, dan SDN Kebonturi) Kecamatan Jaken Kabupaten Pati. Masing-masing sekolah dasar diambil 10 siswa. Jadi, jumlah total menjadi 50 siswa. Produk berupa modul pendidikan karakter berbasis gerakan literasi sekolah. Sebelum pelaksanaan modul pendidikan karakter berbasis gerakan literasi sekolah, siswa, guru, dan kepala sekolah diarahkan untuk mengisi angket sebagai tanggapan tentang karakter siswa di masingmasing sekolahnya. Hal ini dilakukan untuk mengetahui karakter awal siswa sebelum dilakukan perlakuan berupa penerapan modul.

Peneliti bersama guru dan kepala sekolah melaksanakan program pendidikan karakter yang sesuai dengan rancangan dalam modul 


\section{Sri Subiyanti, Murtono, Su'ad \\ PENDIDIKAN KARAKTER BERBASIS GERAKAN LITERASI DI SEKOLAH DASAR \\ REFLEKSI EDUKATIKA : Jurnal Ilmiah Kependidikan, Volume 11, Nomor 1, Desember 2020, hlm. 24-34}

pendidikan karakter berbasis gerakan literasi sekolah. Dua minggu pertama, masing-masing SD merancang kegiatan literasi sesuai dengan masing-masing karakter yang akan menjadi ciri khasnya. Minggu ke-3 dan ke-4 setiap hari Sabtu, SDN Sumberejo sebagai duta karakter displin menjadi SD yang dikunjungi.

Minggu ke-5 dan ke-6, SDN Sukorukun sebagai duta karakter gemar membaca menjadi SD yang dikunjungi. Minggu ke-7 dan ke-8, SDN Tegalarum sebagai duta karakter tanggung jawab menjadi SD yang dikunjungi. Minggu ke9 dan ke-10, SDN Mojoluhur sebagai duta karakter rasa ingin tahu menjadi SD yang dikunjungi.

Minggu ke-11 dan ke-12, SDN Kebonturi sebagai duta karakter komunikatif menjadi SD yang dikunjungi. Setelah pelaksanaan modul ini berakhir, kegiatan selanjutnya adalah memberikan lembar angket kepada siswa, guru, dan kepala sekolah untuk mengisi angket sebagai hasil dari keterlaksanaan modul. Kegiatan ini untuk mengetahui karakter siswa setelah dilaksanakan modul pendidikan karakter berbasis gerakan literasi sekolah.

Setelah penerapan modul dan pengisian angket, guru memberikan tanggapan mengenai keterlaksanaan modul pendidikan karakter berbasis gerakan literasi sekolah dengan mengisi lembar observasi. Rata-rata guru sekolah dasar di Gugus RA Kartini Kecamatan Jaken Kabupaten Pati memberikan tanggapan secara klasikal mencapai 75,6 \%. Hal ini disimpulkan bahwa tanggapan guru terhadap pelaksanaan modul ini adalah baik.

\section{Produk Final}

Modul pendidikan karakter berbasis gerakan literasi sekolah adalah produk akhir hasil dari penelitian ini. Setelah melalui tahap revisi dan uji coba terbatas, maka pada bagian pertama modul berupa sampul awal, selanjutnya bagian awal modul, isi modul, bagian akhir modul, dan sampul belakang.

Bagian sampul awal terdiri atas gambar, judul modul, dan penulis modul. Selanjutnya pada bagian awal modul terdiri atas kata pengantar, daftar isi, dan daftar gambar. Isi modul terdiri atas lima bab, yaitu bab 1 pendahuluan, bab 2 tata kelola dan daya dukung, bab 3 implementasi pendidikan karakter berbasis GLS, bab 4 pendampingan, dan bab 5 penilaian dan evaluasi program. Pada bagian akhir modul terdiri dari daftar pustaka. Terakhir, modul ditutup dengan sampul belakang yang berisi gambar, penjabaran singkat modul, dan tujuan yang akan dicapai.

Pada modul berjudul "Pendidikan Karakter Berbasis Gerakan Literasi Sekolah Dasar" yang dikembangkan peneliti menggunakan jenis huruf times new roman dengan font 12 pada penjabaran materi. Penggunaan jenis huruf ini bertujuan untuk memudahkan pembaca menggunakan modul yang dikembangkan peneliti. Kemudian penggunaan bahasa yang sederhana dan komunikatif pada modul yang dikembangkan peneliti mempermudah pembaca memahami isi materi yang terkandung sehingga mudah untuk menerapkannya.

Ukuran modul berpedoman pada ukuran kertas berdasarkan ISO, yaitu $210 \times 297 \mathrm{~mm}$. Secara keseluruhan modul ini terdiri dari 59 halaman. Pada bagian isi modul dijabarkan contoh program pelaksanaan modul dan berbagai gambar untuk mendukung keterangan yang bersifat abstrak supaya mempermudah pembaca yang akan menerapkan modul ini.

\section{B. Pembahasan}

\section{Analisis Data}

Pada tahapan ini, peneliti melakukan analisis karakter siswa berdasarkan hasil pengisian angket sebelum dan sesudah dilaksanakan modul pendidikan karakter berbasis gerakan literasi sekolah. Hasil pengisian angket antara sebelum dan sesudah pelaksanaan modul disajikan pada tabel berikut.

Tabel 1. Perbandingan Karakter Siswa Sebelum dan Sesudah Menerapkan Modul

\begin{tabular}{clll}
\hline No & Aspek & Sebelum & Sesudah \\
\hline 1 & Gemar membaca & $43,00 \%$ & $74,80 \%$ \\
2 & Rasa ingin tahu & $46,40 \%$ & $76,40 \%$ \\
3 & Disiplin & $48,00 \%$ & $77,80 \%$ \\
4 & Bertanggung jawab & $49,80 \%$ & $79,40 \%$ \\
5 & Komunikatif & $50,50 \%$ & $79,70 \%$ \\
& Rata-rata & $47,54 \%$ & $77,62 \%$ \\
\hline
\end{tabular}

Dari tabel tersebut dapat dijelaskan bahwa karakter gemar membaca siswa yang awalnya hasil angket menunjukkan $43,00 \%$, maka setelah penerapan modul pendidikan karakter berbasis gerakan literasi di sekolah dasar menjadi meningkat sebesar $74,80 \%$. Karakter rasa ingin tahu siswa yang awalnya menunjukkan $46,40 \%$, maka setelah penerapan modul pendidikan karakter berbasis gerakan literasi di sekolah dasar menjadi meningkat sebesar 76,40\%. 
Karakter disiplin siswa yang awalnya menunjukkan $48,00 \%$, maka setelah penerapan modul pendidikan karakter berbasis gerakan literasi di sekolah dasar menjadi meningkat sebesar $77,80 \%$. Karakter bertanggung jawab siswa yang awalnya hasil angket menunjukkan 49,80\%, maka setelah penerapan modul pendidikan karakter berbasis gerakan literasi di sekolah dasar menjadi meningkat sebesar $79,40 \%$.

Karakter bersahabat/komunikatif siswa yang awalnya menunjukkan 50,50\%, maka setelah penerapan modul pendidikan karakter berbasis gerakan literasi di sekolah dasar menjadi meningkat sebesar 79,70\%. Sehingga secara keseluruhan rata-rata pendidikan karakter siswa yang awalnya hanya $47,54 \%$ meningkat menjadi $77,62 \%$. Hal ini menunjukkan bahwa penerapan modul pendidikan karakter berbasis gerakan literasi di sekolah dasar memberikan dampak yang positif terhadap perbaikan karakter siswa.

Data tersebut juga didukung dengan hasil penelitian yang relevan oleh penelitian yang dilakukan Respati (2018) yaitu implementasi gerakan literasi sekolah dalam menanamkan karakter membaca siswa SD kelas tinggi. Hasil temuan penelitian ini yaitu dengan melaksanakan gerakan literasi sekolah dengan menggunakan metode 15 menit membaca hasilnya dapat menanamkan karakter gemar membaca siswa kelas tinggi di SD Negeri 1 Sawahan. Jadi, dengan kegiatan literasi, maka karakter gemar membaca dapat berkembang lebih baik dan mempengaruhi karakter baik yang lain.

Berikut perbandingan karakter siswa antara sebelum dan sesudah penerapan modul.

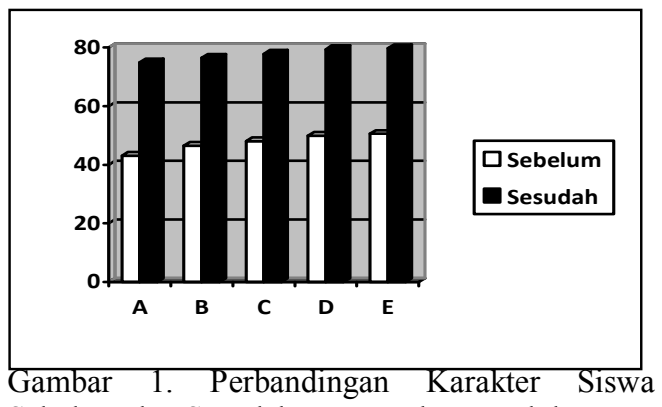

Sebelum dan Sesudah Menerapkan Modul

Berdasarkan gambar di atas, garis horizontal adalah karakter siswa yang dikembang, (A) gemar membaca, (B) rasa ingin tahu, (C) disiplin, (D) bertanggung jawab, komunikatif.

Hasil pengisian angket antara sebelum dan sesudah pelaksanaan modul kemudian dianalisis menggunakan uji t. Pengujian hipotesis yang digunakan yaitu t-test berkorelasi uji fihak kanan karena hipotesis alternatif $\left(\mathrm{H}_{\mathrm{a}}\right)$ berbunyi lebih baik. Pengujian dilakukan menggunakan excel, $t$ test paired two samples for means yang disajikan dalam tabel berikut.

Tabel 2. t-Test Paired Two Samples for Means

\begin{tabular}{lrr}
\hline Aspek & Variable 1 & Variable 2 \\
\hline Mean & 47,54 & 77,62 \\
& & 42,7302040 \\
Variance & 40,37591837 & 8 \\
Observations & 50 & 50 \\
Pearson Correlation & 0,963630196 & \\
Hypothesized Mean & & \\
Difference & 0 & \\
Df & 49 & \\
t Stat & $-121,6967519$ & \\
P $(\mathrm{T}<=$ t) one-tail & $8,91812 \mathrm{E}-63$ & \\
t Critical one-tail & 1,676550893 & \\
P $(\mathrm{T}<=\mathrm{t})$ two-tail & $1,78362 \mathrm{E}-62$ & \\
t Critical two-tail & 2,009575199 & \\
\hline
\end{tabular}

Dari tabel di atas diperoleh nilai statistik = 121,696 dan $\mathrm{dk}=48, \alpha=5 \%$ diperoleh $\mathrm{t}$ tabel $=$ 1,68. Karena $\mathrm{t}$ hitung $=-121,696$ jatuh pada penerimaan $\mathrm{H}_{\mathrm{a}}$ atau $\mathrm{H}_{0}$ ditolak. Sehingga disimpulkan bahwa efektivitas modul terhadap karakter siswa sesudah penggunaan modul pendidikan karakter berbasis GLS lebih baik daripada sebelum menggunakan modul. Jadi, modul ini efektif untuk diimplementasikan sebagai pengembangan pendidikan karakter di sekolah dasar.

\section{Modul Pendidikan Karakter Berbasis Gerakan Literasi Sekolah}

Pengembangan modul pendidikan karakter berbasis gerakan literasi sekolah dilakukan untuk memperbaiki karakter siswa sejak usia sekolah dasar sebagai bekal menuju masa remaja. Selain itu, modul ini memfasilitasi siswa supaya dapat terbiasa dengan berliterasi yang nantinya dapat meningkatkan minat membaca siswa. Berdasarkan jenis penelitian yang dilakukan, peneliti telah menghasilkan produk modul pendidikan karakter berbasis gerakan literasi sekolah.

Anwar (2010) menyatakan modul adalah buku yang disusun secara sistematis dan menarik, mencakup isi materi, metode, dan evaluasi yang dapat digunakan secara mandiri 
untuk mencapai kompetensi. Berdasarkan teori tersebut, modul yang telah dihasilkan berupa modul pendidikan karakter disusun secara sistematis dan isinya telah disusun berdasarkan program gerakan literasi sekolah sesuai tuntutan dalam kurikulum 2013. Dimana kegiatan literasi melalui tiga tahap, yaitu pembiasaan, pengembangan, dan pembelajaran yang telah dikembangkan menjadi beberapa kegiatan sehingga mempermudah pengguna modul untuk mencapai tujuan pendidikan karakter secara maksimal.

Pengembangan modul karakter berbasis gerakan literasi sekolah ini disesuaikan dengan karakteristik lingkungan satuan pendidikan masing-masing. Sehingga modul ini dapat digunakan di sekolah dasar manapun dan disesuaikan dengan sarana dan prasarana yang ada.

Pada penelitian yang telah dilakukan, kelebihan dari modul pendidikan karakter berbasis gerakan literasi sekolah terlihat dari tanggapan guru dan kepala sekolah melalui lembar observasi dan wawancara saat pelaksanaan modul, seperti: siswa memiliki pengalaman belajar dalam hal pendidikan karakter dan berliterasi yang lebih dibandingkan dengan penanaman pendidikan karakter sebelumnya, siswa mampu melakukan study banding karakter dan menyerap karakter dari sekolah lain untuk diterapkan di sekolahnya, siswa termotivasi untuk membaca karena beragam lokasi yang menarik dan keragaman sumber bacaan sebagai bahan literasi, siswa akan merasakan menjadi duta karakter/teladan berkarakter untuk teman-teman yang lain.

Dalam materi modul dijelaskan pola pendampingan dan evaluasi kegiatan. Hal ini dimaksudkan untuk mempermudah pengguna modul dalam menerapkan dan memberikan evaluasi untuk perbaikan kegiatan selanjutnya dengan mengembangkan jenis karakter yang lain sampai terpenuhi 18 karakter pancasila.

Implementasi modul pendidikan karakter berbasis gerakan literasi di sekolah dasar ini relevan dengan penelitian yang dilakukan oleh Novianti (2017) yang menyatakan bahwa penanaman pendidikan karakter efektif dilakukan melalui sebuah cerita dalam novel. Sehingga dengan membaca cerita atau novel, siswa dapat memetik amanat yang baik dan meniru tokoh protagonis dalam cerita atau novel tersebut.
Penelitian yang relevan juga dilakukan oleh Hidayati, et al. (2014) yang menyatakan bahwa pendidikan karakter diterapkan di sekolah dasar melalui pengembangan kurikulum. Jadi, dengan kurikulum yang dikembangkan adanya pembiasaan kegiatan literasi sekolah membaca 15 menit sebelum kegiatan pembelajaran, maka hal tersebut dapat meningkatkan karakter siswa di sekolah sejak usia dini.

Berdasarkan hasil penelitian yang relevan, maka modul pendidikan karakter berbasis gerakan literasi ini dapat dijadikan sebagai pedoman dalam implementasi pendidikan karakter di sekolah dasar.

\section{Kelayakan Modul Pendidikan Karakter Berbasis Gerakan Literasi Sekolah}

Uji kelayakan pada tahap validasi desain terdiri dari aspek kelayakan isi, kelayakan pelaksanaan dan berbasis gerakan literasi sekolah, aspek kelayakan bahasa, dan kelayakan kegiatan siswa. Modul divalidasi oleh validator ahli materi dan ahli modul. Perolehan skor dari validator ahli materi adalah $83 \%$ (sangat layak) dan validator ahli modul adalah $75 \%$ (layak).

Jadi, dapat disimpulkan bahwa modul pendidikan karakter berbasis gerakan literasi sekolah ini layak untuk diterapkan di sekolah dasar. Hal ini didukung oleh Perdana (2018:185) bahwa penanaman nilai-nilai karakter kepada siswa memerlukan strategi pembelajaran dan keahlian tersendiri.

Penelitian yang sama dengan penelitian ini juga pernah dilakukan oleh Rahayu, et al. (2017) menyatakan bahwa upaya penumbuhan karakter siswa SD dilakukan dengan gerakan literasi sekolah. Dalam jurnalnya menelaah tentang pelaksanaan gerakan literasi sekolah dan ekosistem literat di sekolah dasar yang dapat menumbuhkan karakter pada siswa melalui tahapan pembiasaan, pengembangan, dan pembelajaran. Sehingga modul pendidikan karakter berbasis gerakan literasi di sekolah dasar ini dapat dijadikan alternatif strategi untuk penanaman pendidikan karakter di sekolah dasar.

\section{Keefektifan Modul Pendidikan Karakter} Berbasis Gerakan Literasi Sekolah

Hasil pengisian angket antara sebelum dan sesudah pelaksanaan modul kemudian dianalisis menggunakan uji t. Hipotesis dalam penelitian ini adalah:

$\mathrm{H}_{\mathrm{o}}$ : efektivitas modul pendidikan karakter berbasis gerakan literasi di sekolah dasar sesudah menggunakan modul lebih kecil 
atau sama dengan sebelum menggunakan modul.

$\mathrm{H}_{\mathrm{a}}$ : efektivitas modul pendidikan karakter berbasis gerakan literasi di sekolah dasar sesudah menggunakan modul lebih baik dari sebelum menggunakan modul.

Pengujian hipotesis yang digunakan yaitu ttest berkorelasi uji fihak kanan karena hipotesis alternatif $\left(\mathrm{H}_{\mathrm{a}}\right)$ berbunyi lebih baik (Sugiyono, 2014:424). Pengujian dilakukan menggunakan excel, t-test paired two samples for means diperoleh nilai statistik $=-121,696 \mathrm{dan} \mathrm{dk}=48$, $\alpha=5 \%$ diperoleh $\mathrm{t}$ tabel $=1,68$. Karena $\mathrm{t}$ hitung $=-121,696$ jatuh pada penerimaan $\mathrm{H}_{\mathrm{a}}$ atau $\mathrm{H}_{0}$ ditolak. Sehingga disimpulkan bahwa efektivitas modul terhadap karakter siswa sesudah penggunaan modul pendidikan karakter berbasis GLS lebih baik daripada sebelum menggunakan modul.

Selain uji t, data ini didukung secara kuantitatif klasikal hasil dari pengisian angket, rata-rata karakter siswa mengalami peningkatan yang awalnya hanya 47,54\% (sebelum diterakan modul) menjadi $77,62 \%$ (sesudah diterapkan modul).

Modul pendidikan karakter berbasis gerakan literasi sekolah ini juga didukung oleh penelitian Azizah dan Setiana (2016) yang menyatakan bahwa penanaman pendidikan karakter dapat diterapkan melalui karya sastra sebuah novel dengan meneladani sikap tokoh. Nilai-nilai karakter yang terkandung dalam sumber bacaan literasi dapat diimplementasikan oleh siswa dalam kehidupan sehari-hari. Sastra menjadi media yang tepat dalam menanamkan karakter positif bagi siswa (Setiawati, 2015:65).

Penelitian ini didukung oleh riset Hendrawan, et al. (2017) yang menyatakan bahwa penanaman pendidikan karakter dapat diterapkan melalui gerakan literasi sekolah berdasarkan perspektif pedagogik kritis. Hal ini memandang secara mendasar bahwa penanaman nilai-nilai karakter siswa melalui gerakan literasi di SD merupakan suatu proses pemanusiaan atau proses pendidikan di dalam kancah pergumulan berbagai struktur kekuasaan atau kegiatan yang menimpa manusia.

5. Respon Guru tentang Dampak Modul Pendidikan Karakter Berbasis Gerakan Literasi Sekolah

Setelah penerapan modul dan pengisian angket, guru memberikan tanggapan mengenai keterlaksanaan modul pendidikan karakter berbasis gerakan literasi sekolah dengan mengisi lembar observasi. Berikut disajikan data mengenai hasil tanggapan guru berdasarkan observasi keterlaksanaan modul pendidikan karakter berbasis gerakan literasi sekolah.

Tabel 3. Hasil Observasi Tanggapan Guru terhadap Keterlaksanaan Modul

\begin{tabular}{cccccccc}
\hline No & Sekolah & A & B & C & D & E & $\begin{array}{c}\text { Rata- } \\
\text { rata }\end{array}$ \\
\hline 1 & SDN Sukorukun & 15 & 16 & 15 & 16 & 18 & $80 \%$ \\
2 & SDN Sumberejo & 14 & 17 & 14 & 16 & 16 & $77 \%$ \\
3 & SDN Tegalarum & 15 & 12 & 15 & 16 & 18 & $76 \%$ \\
4 & SDN Mojoluhur & 14 & 16 & 15 & 15 & 16 & $76 \%$ \\
5 & SDN Kebonturi & 13 & 16 & 12 & 14 & 14 & $69 \%$ \\
& Jumlah & 71 & 77 & 71 & 77 & 82 & $75,6 \%$ \\
\hline
\end{tabular}

Berdasarkan tabel di atas, ada lima aspek yang diobservasi untuk menilai keterlaksanaan modul pendidikan karakter berbasis gerakan literasi sekolah, yaitu aspek: (A) nilai-nilai pendidikan karakter yang diimplementasikan melalui modul, (B) proses implementasi modul, (C) evaluasi yang digunakan untuk menunjang keberlanjutan implementasi modul, (D) kondisi siswa setelah pelaksanaan modul, (E) kondisi saran dan prasarana di SD se-Gugus RA Kartini. Dalam kegiatan penerapan modul pendidikan karakter berbasis gerakan literasi sekolah ini, guru terlibat langsung. Guru harus menjadi teladan, peran guru mendorong siswa menerapkan moral, dan guru harus terlibat dalam proses penanaman pendidikan karakter (Kusminah, 2012).

Rata-rata guru sekolah dasar di Gugus RA Kartini Kecamatan Jaken Kabupaten Pati memberikan tanggapan secara klasikal mencapai $75,6 \%$. Hal ini disimpulkan bahwa tanggapan guru terhadap pelaksanaan modul ini adalah baik.

Meskipun karakter seorang siswa dibentuk oleh lingkungan sosial, tetapi sekolah masih membutuhkan pelaksanaan pendidikan karakter yang membekali siswa dengan karakteristik yang tepat untuk membantu mereka menjadi warga negara yang baik (Agboola dan Tsai, 2012:168). Sehingga modul ini dapat dijadikan salah satu alternatif strategi untuk sekolah dalam menanamkan karakter kepada siswa.

\section{SIMPULAN}

Berdasarkan analisis data dan pembahasan pada penelitian, dapat diambil simpulan sebagai berikut: 
1. Modul pendidikan karakter berbasis gerakan literasi sekolah telah memenuhi kriteria valid dan layak dari penilaian para ahli materi dan ahli modul dari aspek kelayakan isi, kelayakan pelaksanaan, aspek kelayakan bahasa, dan kelayakan kegiatan siswa. Modul pendidikan karakter berbasis gerakan literasi sekolah dinyatakan layak karena didapatkan persentase kriteria kelayakan validator $83 \%$ (sangat layak) dan $75 \%$ (layak).

2. Modul pendidikan karakter berbasis gerakan literasi sekolah dinyatakan efektif untuk memperbaiki karakter siswa dan digunakan di sekolah dasar. Hal ini terbukti dengan rata-rata karakter siswa berdasarkan hasil angket sebelum dilaksanakan modul dan sesudah dilaksanakan modul yaitu 47,54\% menjadi $77,62 \%$. Karakter siswa mengalami peningkatan sebesar $30,08 \%$. Sedangkan uji $\mathrm{t}$ (efektifitas) sebesar $-121,696<1,86$ sehingga menerima $\mathrm{H}_{\mathrm{a}}$.

3. Modul pendidikan karakter berbasis gerakan literasi sekolah memberikan dampak yang baik untuk meningkatkan karakter baik siswa dan meningkatkan minat baca siswa. Hal ini mendapat respon baik dari tanggapan guru SD se-Gugus RA Kartini Kecamatan Jaken Kabupaten Pati dengan hasil persentase 75,6\% (baik).

4. Modul pendidikan karakter berbasis gerakan literasi sekolah dapat dimanfaatkan sebagai pendamping dalam penerapan pendidikan karakter di sekolah dasar yang sudah dilaksanakan. Hal ini bertujuan untuk memperkuat implementasi PPK dan literasi pada pembelajaran sesuai Kurikulum 2013 revisi tahun 2018 .

\section{DAFTAR PUSTAKA}

Agboola, Alex dan Kaun Chen Tsai. 2012. Bring Character Education into Classroom. European Journal of Educational Research, 1 (2): 168.

Anwar, Ilham. 2010. Pengembangan Bahan Ajar. Bahan Kuliah Online. Bandung: Direktori UPI.

Azizah, Aida dan Setiana, Leli Nisfi. 2016. Karakter Tokoh dalam Novel Langit Mekah Berkabut Merah Karya
Geidurrahman Al-Mishry Berbasis NilaiNilai Karakter Religius dan Implikasinya dalam Pembelajaran Sastra di Madrasah Aliyah. Refleksi Edukatika : Jurnal Ilmiah Kependidikan, 7 (1): 77-83.

Hendarman, et al. 2017. Penguatan Pendidikan Karakter. Jakarta: Pusat Analisis dan Sinkronisasi Kebijakan (PASKA) Sekretariat Jenderal kementerian Pendidikan dan Kebudayaan.

Hendrawan, Budi, et al. 2017. Kajian Aplikatif Penanman Nilai-Nilai Karakter Siswa melalui Gerakan Literasi di Sekolah Dasar berdasarkan Perspektif Pedagogik Kritis. Jurnal Pendidikan dan Pembelajaran Sekolah Dasar, 1 (2a).

Hidayati, Abna, et al. 2014. The Development of Character Education Curriculum for Elementary Student in West Sumatera. International Journal of Education and Research, 2 (6): 189.

Ismaya, Erik Aditia. 2017. Pembelajaran Konsep Ilmu Pengetahuan Sosial Berbasis Literasi Informasi Untuk Mendukung Pencapaian Visi Universitas Kebudayaan. Prosiding Seminar Nasional Aktualisasi Kurikulum 2013 Di Sekolah Dasar Melalui Gerakan Literasi Sekolah Untuk Menyiapkan Generasi Unggul Dan Berbudi Pekerti, 123-134.

Kesuma, Dharma., et al. 2011. Pendidikan Karakter Kajian Teori dan Praktik di Sekolah. Bandung: PT Remaja Rosdakarya.

Khoury, Ruba. 2017. Character Education as a Bridge from Elementary to Middle School: A Case Study of Effective Practices and Processes. International Journal of Teacher Leadership, 8 (2): 6263.

Kusminah. 2012. Pengembangan Model Pembelajaran Induktif Kata Bergambar Bermuatan Nilai-Nilai Pendidikan Karakter Aspek Membaca Permulaan Sekolah Dasar. Journal of Education Research and Evaluation, 1 (2): 119. 
Sri Subiyanti, Murtono, Su'ad

PENDIDIKAN KARAKTER BERBASIS GERAKAN LITERASI DI SEKOLAH DASAR

REFLEKSI EDUKATIKA : Jurnal Ilmiah Kependidikan, Volume 11, Nomor 1, Desember 2020, hlm. 24-34

Masfuah, Siti. 2015. Pengaruh Kecakapan Personal Terhadap Literasi Sains Siswa. REFLEKSI EDUKATIKA : Jurnal Ilmiah Kependidikan, 5 (2):

Novianti, Nita. 2017. Teaching Character Education to College Students Using Bildungsromans. International Journal of Instruction, 10 (4): 267.

Pala, Aynur. 2011. The Need for Character Education. International Journal of Social Sciences and Humanity Studies, 3 (2): 2332.

Perdana, Novrian Satria. Implementasi Peranan Ekosistem Pendidikan dalam Penguatan Pendidikan Karakter Peserta Didik. Refleksi Edukatika : Jurnal Ilmiah Kependidikan, 8 (2): 183-191.

Rahayu, Ratih Agustina, et al. 2017. Gerakan Literasi Sekolah sebagai Upaya Penumbuhan Karakter Siswa Sekolah Dasar. Prosiding TEP \& PDs, Tema: 7 Nomor 15, 1060-1067.
Respati, Choiri Bayu. 2018. Implementasi Gerakan Literasi Sekolah dalam Menanamkan Karakter Gemar Membaca Siswa Kelas Tinggi di SD Negeri 1 Sawahan. Publikasi Ilmiah. Surakarta: Universitas Muhammadiyah Surakarta.

Setiawati, Lis. 2015. Pembentukan Karakter Siswa Melalui Pembelajaran Bahasa dan Sastra Indonesia. Jurnal Pendidikan, 16 (1): 65 .

Siregar, Y. E. Y., Zulela, M. S., Prayuningtyas, A. W., Rachmadtullah, R., dan Pohan, N. Self Regulation, Emotional Intelligence With Character Building In Elementary School. In Annual Civic Education Conference (ACEC 2018). Atlantis Press.
Suntoro. 2019. Literasi Informasi Guru Pendidikan Agama Buddha Dan Implikasinya Dalam Pembelajaran. REFLEKSI EDUKATIKA : Jurnal Ilmiah Kependidikan, 9 (2): 182-191.

Sugiyono. 2014. Statistika untuk Penelitian. Bandung: Alfabeta.

Wiratsiwi, Wendri. 2020. Penerapan Gerakan Literasi Sekolah Di Sekolah Dasar. REFLEKSI EDUKATIKA : Jurnal Ilmiah Kependidikan, 10 (2): 230-238 